Boise State University ScholarWorks

Public Policy and Administration Faculty

Publications and Presentations

Department of Public Policy and Administration

4-1-2018

When Need Meets Opportunity: Expanding Local Air Networks

Luke Fowler

Boise State University 
This is an author-produced, peer-reviewed version of this article. The final, definitive version of this document can be found online at The

American Review of Public Administration, published by SAGE. Copyright restrictions may apply. doi: 10.1177/0275074016680026

\title{
When Need Meets Opportunity: Expanding Local Air Networks
}

\author{
Luke Fowler \\ Assistant Professor \\ School of Public Service \\ Boise State University
}

\begin{abstract}
Though the Clean Air Act (CAA) relies on a traditional inter-government partnership, new initiatives from local governments that fall outside of the conventional implementation strategy have created a unique public service delivery network by adding layers to the implementation scheme. Using both logistic and multinomial logistic models and a dataset of 497 Metropolitan (MSA) and Micropolitian ( $\mu \mathrm{SA})$ areas, this research tests a model of network membership for local governments based on internal organizational and external network factors. Findings indicate policy problems, perceptions of resource availability, network density and structure, and socio-economic and political factors affect local initiative to expand networks.
\end{abstract}

\section{Introduction}

Air quality has been a cornerstone of United States (US) environmental policy since the mid-20th century, and has resulted in one of the most complex pieces of legislation on the books in the Clean Air Act (CAA). More interestingly, it has resulted in a unique and dynamic public service delivery network for air quality. CAA implementation is based on an inter-governmental "partnership" between federal, state, and, sometimes, local governments, with state-level discretion in implementation schemes leading to significant variations across the nation (Belden, 2001; Martineau and Novello, 2004). Local government roles are dynamic and they tend to garner little attention from policymakers or scholars (Fowler, 2016). However, local governments have adopted an array of initiatives to complement federal and state efforts and better address local environmental issues, without a structured role such as those afforded to federal and state governments (EPA, 2016d; NAGLEP, 2016). Despite a limited official role, numerous local governments are operating air initiatives, with little recognition from policy makers or scholars. Although operating within a traditional hierarchical relationship with state and federal governments, local governments have taken initiative to expand their programming. Furthermore, local governments have unique policy initiatives that complement rather than extend the regulatory approach of federal and state governments, creating a "partnership" where, essentially, all three governments are seeking the same policy goals but not implementing the same policy. Local governments are working to improve air quality, but not necessarily to implement the CAA.

While there is increasing research on networks, scholarship on how and why these networks form remains limited. Treating networks as a dependent variable can provide insight into why "so much public management [is] situated in settings in which multiple actors and organizations are linked” (O’Toole, 2015, p. 364). Thus, this research seeks to explain why local governments are adding a layer of public service delivery to an already existing policy implementation scheme. After presenting background on public service delivery networks and air quality management, a model of local government membership in air quality networks is formulated. The model is then tested using both logistic and multinomial logistic regression with a cross-sectional dataset of 497 Metropolitan (MSA) and Micropolitian ( $\mu \mathrm{SA})$ areas. Findings indicate network membership for local governments is a function of need and opportunity created by both internal organizational and external network factors.

\section{Networks for Public Service Delivery}

Despite early developments of first- and second-generation implementation studies, theories of the implementation process have stalled out in the last several decades (O'Toole, 2000). Nevertheless, scholars have not stopped researching implementation, and in doing so, have begun to look to networks for theoretical grounding (Lecy, Mergel, and Schmitz, 2014). Research into networks has lacked coherence in many ways, as there have been wide application of the concept and different agendas proposed (O’Toole, 1997, 2015; Kapucu, Hu, and Khosa, 2014; Lecy, et al., 
This is an author-produced, peer-reviewed version of this article. The final, definitive version of this document can be found online at The American Review of Public Administration, published by SAGE. Copyright restrictions may apply. doi: 10.1177/0275074016680026

2014). While difficult to describe, networks abide by a few basics elements. As a whole, "networks are structures of interdependence involving multiple organizations or parts thereof, where one unit is not merely the formal subordinate of the other in some larger hierarchical arrangement" (O'Toole, 2015, p. 361). Other definitions tend to rely on collective action, common goals, and organizational relationships, and research focuses on inter-organizational collaborations, policy goals not effectively achieved by a single organization, and deviations from traditional bureaucratic structures (O’Toole, 1997; Agranoff \& McGuire, 2001; Koliba, Mills, and Zia, 2011; Kapucu, et al., 2014; Lecy, et al., 2014; O’Toole, 2015).

Networks represent a changing position for bureaucratic organizations, not a replacement of them. Layers of organizations are added to traditional bureaucratic machinations and structures become more complex (Frederickson, 1999; Nicolaidis and Howse, 2001; Feiock and Scholz, 2010; O’Toole 2015). Additionally, within the web of organizational connections, actors can play different roles simultaneously, creating conflicts in incentives, missions, and priorities (Hjern and Porter, 1981; O’Toole 2015). Hierarchical authority, regulation, or contract agreements can force organizations into networks, so these roles are not necessarily voluntary, self-governing, or cooperative (Scharpf 1993; O’Toole 2015). This creates an array of networked ties, where actors and organizations are "neither in full agreement with nor in strident opposition to each other but somewhere in between” (O'Toole, 2015, p. 362). While issues of terminology persist, policy implementation networks are a special case of networks (Kapucu, et al., 2014; Lecy, et al., 2014). Policy implementation, collaborative, or public service delivery networks focus on coordination of efforts by multiple actors in public service delivery. They rely on connections that are not traditional bureaucratic structures, such as hierarchies, single agency, or marketplaces (Kapucu, et al., 2014; Lecy, et al., 2014). In these networks, organizations exhibit independence. Although, power asymmetries do exist as actors control resources and access, and studies emphasize variation across networks in understanding differences in public service delivery. Policy implementation network research is concerned with service delivery, rather than the governance process itself, so these power asymmetries are an explanatory rather than a dependent variable (Provan and Milward, 2001; Kapucu, et al., 2014; Lecy, et al., 2014; O’Toole, 2015).

While the primary focus has been on processes and outcomes, an alternative key point of the network research agenda for public administration is concerned with networks as a dependent variable (O'Toole, 1997, 2015). While many questions remain, extant scholarship demonstrates a few important points on network formation in public service delivery. Foremost, factors effecting network formations vary, based on network type, policy problem, and sector (O’Toole, 2015). Analyzing 411 subnational government programs in Thailand, Krueathep, Riccucci, and Suwanmala (2010) found institutional setting, program areas, management capacity, political climate, and socio-economics all played into network formation. Findings from inter-local agreements between 44 local governments in the Detroit metropolitan area indicate municipalities are more likely to cooperate in system maintenance services, such as public works projects, than in lifestyle services, such as public housing (LeRoux and Carr, 2010). Jasny (2012), analyzing organizations involved in San Francisco Bay Area watershed policy, found a certain degree of interaction between organizational type and network association. Isett and Provan (2005) found inter-organizational links form differently for public and non-profit sectors compared to for-profit organizations providing mental health services in Pima County, Arizona. Unsurprisingly, there is a significant degree of variation in the specifics of network formation and very few “one-size-fits-all” lessons. As a whole, extant scholarship indicates both internal organizational and external variables explain the size and scope of networks (Graddy and Chen, 2006; Andrews et. al., 2011).

\section{Internal Pressures}

Factors internal to organizations drive the want and/or need for networked public service delivery. Scholars have identified internal organizational factors that create an internal predisposition for network participation. Chief among these internal factors are resource and programmatic needs and perceptions. Individual actors will seek partnerships in order to gain resources to meet shared policy goals, making programmatic needs and resource dependency key factors in network formation (Graddy and Chen, 2006). There is an expectation of reciprocity between partners defined by a complex relationship where actors hope to extract resources from networks in order to address common goals (Graddy and Chen, 2006; Lee, Lee, and Feiock, 2012; Park and Rethemeyer, 2014). Of course, these resources can be either tangible (e.g., funding) or intangible (e.g., credibility), with resource tangibility effecting interactions (Provan and Huang, 2012). However, as resources contract, networks became segmented and relationships change (Park and Rethemeyer, 2014). Thus, networks are "animated by a desire to control resource dependence" due to a 
This is an author-produced, peer-reviewed version of this article. The final, definitive version of this document can be found online at The American Review of Public Administration, published by SAGE. Copyright restrictions may apply. doi: 10.1177/0275074016680026

balancing act between resource holders and seekers (Park and Rethemyer, 2014, p. 375). Social clustering helps alleviate some of these pressures by creating complex interactions to maintain commitments to resources and solutions (Lee, Lee, and Feiock, 2012).

Internal organizational perceptions of commitments to resources and goals, and risk are definitive issues as well. Andrew (2009) argues local governments will reduce commitment risk and seek to pool resources through seeking 'high status' partners and/or collaborating with their existing partners' partners. Further findings suggest reducing political risks of collaboration is a key motivation when seeking partners (Feiock, Lee, Park, and Lee, 2010). When framed as regional-level competition, it encourages regional governance networks, as individual actors begin to seek more resources to enhance their own competitiveness (Lee, Feiock, and Lee, 2012). Overcoming competition locally requires trust between partners. Perceptions of trustworthiness reduces organizational desire to compete and instead encourages collaboration. Network actors will actually create mechanisms to build trust as risk in collaboration grows (Feiock, et. al., 2010; Bunger, 2013). Furthermore, cooperative agreements are more likely to occur when senior administrators and/or elected officials participate in the same professional associations (LeRoux and Carr, 2010). In sum, internal to organizations is the need for resources to meet goals, and perceptions of networks in providing for those needs and achievement of common goals.

\section{External Opportunities}

Factors external to the organization create opportunities for network formation as well. Network structures reverberate throughout networks by creating patterns of interactions between actors (Fischer, Ingold, Sciarini, and Varone, 2012). These structures create preconditions that allow new organizations to enter networks, or at least, frame internal organizational perceptions of the costs and benefits of association. In that, networks have to create a balance between "loose" structure that allows for new partnerships and "embeddedness" between partners. Associations allowing for more open entry and stakeholder diversity have been positively associated with networking management (O'Toole, 2015). Laven, et. al., (2010) argue National Heritage Areas have proven to be an effective model of network formation, as the relatively open structure has allowed inter-sectoral partners to become involved, by limiting barriers to collaboration. That is, these so-called "loose" structures allow partners to enter networks with lower capital costs and risk (O’Toole, 2015).

Alternatively, when networks lack a foundation to embed partnerships, they falter. Uncoordinated goals, defensive strategies, and unpredictable demands from partners are all negatively associated with network success (Robins, Bates, and Pattison, 2011; O’Toole, 2015). Robins, et al. (2011) argue legislative changes in management of the Swan River in Western Australia undermined both relational (i.e., partners considering one another's goals) and structural (i.e., connections between partners) "embeddedness" of network partnerships leading to organizations pursuing different goals. Furthermore, availability of network partners, network density, and social clustering effect formation, where partnerships have to offer opportunity for contributions and benefits. Networks lacking sufficient structure to allow for concrete participation and benefits from network actors are unlikely to achieve collective goals, and would be unattractive to potential partners (Graddy and Chen, 2006; Jasny, 2012; Lee, Lee, and Feiock, 2012). Finally, scholars have also noted external socio-economic and political conditions effect network formation in the same way they effect more traditional bureaucracies and implementation processes (Graddy and Chen, 2006; Krueathep, et al., 2010).

\section{Managing Air Quality}

The CAA cements the federal-state partnership for implementation. The EPA establishes air quality standards and the states implement those standards (Belden, 2001: Fowler, 2014). Chief among the EPA's air quality mission is establishment of the National Ambient Air Quality Standards (NAAQS), for all ambient air, outdoor air external to buildings, and for protection of human health and general welfare. Based on available scientific research, the EPA sets ceilings for emissions levels for six criteria pollutants linked to negative health and environmental impacts: carbon monoxide (CO), lead ( $\mathrm{Pb}$ ), nitrogen dioxide (NO2), ozone (O3), particulate matter (PM), and sulfur dioxide (SO2). Primary standards provide for public health for the general population; secondary standards, for general welfare, such as protection of buildings, animals, and vegetation (Belden, 2001; EPA, 2016e). Air Quality Control Regions (AQCRs), which tend to align with MSAs or $\mu$ SAs, form the geographic basis for air quality monitoring. All AQCRs are rated as in attainment or nonattainment with NAAQS, and the overarching goal of implementation is to achieve and maintain attainment (Belden, 2001; Martineau and Novello, 2004; Fowler, 2014). 
This is an author-produced, peer-reviewed version of this article. The final, definitive version of this document can be found online at The American Review of Public Administration, published by SAGE. Copyright restrictions may apply. doi: 10.1177/0275074016680026

States are required to develop State Implementation Plans (SIPs), which form the basis of implementation strategies within each state (EPA, 2016f). These SIPs are a montage of "EPA-approved control strategies and regulations which may include state statutes, rules, transportation control measures, emission inventories, and local ordinances” designed to meet the CAA goals of attainment (Belden 2001, p. 23). There is no specific template for SIPs and they vary from state to state. The general requirements are enforceable emissions limitations, enforcement actions, adequate funding and staffing, legal authority, air quality monitoring and reporting, and consultation with local political subdivisions (Belden, 2001). Within this framework, states have discretion in achieving their goals, with the EPA's role chiefly oversight (Belden, 2001; Martineau and Novello, 2004; EPA, 2016f). In the event states fail to uphold their obligations, the EPA can assume responsibility for day-to-day operations. All 50 states currently have operational control over air programs (ECOS, 2016). According to the US Government Accountability Office (GAO), the delegation approach to implementation is successful as it allows for substantive inter-state variation, but variation that best meets local needs (GAO, 2007). Nevertheless, local governments are emerging in a key role in air quality, as they "are uniquely situated to lead clean air strategies because they understand local conditions and can best influence local practices that connect environmental, economic development, and community goals" (NALGEP, 2016, p. 2). Additionally, a growing class of environmental organizations and policy professionals operating at local-levels have facilitated innovation (Rabe, 2013).

Roles vary greatly in responsibility and willingness to innovate. California's SIP relies on local air planning districts to work with state and local entities for regional air planning (EPA, 2016d). Allegheny County, Pennsylvania has been delegated authority from the state to enforce air quality regulations in its region (ICMA, 2016). In many large metropolitan areas, such as Houston, Texas or Washington, D.C., existing MPOs are integrating air quality into their efforts (Dodge, 2001; Kemp, 2003). On the other hand, these initiatives come with more locally specific approaches, unrelated to SIPs. Miami-Dade County, Florida developed a public outreach program surrounding National Clean Air Month to make citizens more aware of air quality issues and the role they play. Lincoln-Lancaster County, Nebraska utilized municipal engineers as consultants for private business to determine how to cost-effectively reduce emissions. Fort Worth, Texas created a program to encourage municipal employees to utilize alternative transportation options to reduce mobile source emissions. Hamilton County, Ohio retrofitted school buses with diesel oxidation catalysts and promoted an anti-idling campaign to reduce schoolchildren's emission exposure. (See NALGEP, 2016 or NAC, 2016 for more details on specific programs). Still in many states, local governments play no role officially or unofficially in the CAA implementation, but are still responsible for regulations concerning emissions sources (e.g, waste-to-energy plants, vehicle fleets, etc.) (ICMA, 2016).

In a 40 state survey, Woods and Potoski (2010) note 22 states allow local operation of air monitoring stations, and 12 states allow local inspection and enforcement actions. Local governments do not serve simply as subunits of state governments. In some cases, local governments do in fact have delegated authority from the states to implement portions of SIPs. However, in most cases, local governments are not functioning as administrative subunits of state governments in the implementation of SIPs. Local governments are taking on independent action not only for inspection and monitoring but also other initiatives (Woods and Potoski, 2010; Fowler, 2016). Previous research indicates these local governments are successful in improving local air quality, even though they fall outside of the textbook CAA and SIP framework (Fowler, 2016). The exact role varies depending on the specific local government, but as a whole this class of local government is supplementing the larger air quality management scheme in the U.S.

The National Association of Clean Air Agencies (NACAA) lists 117 local government members with dedicated air quality offices (NACAA, 2016). Based on the NACAA membership role, these local governments include cities and counties ranging in size from 21,000 to more (Evanston, Wyoming) than 19 million residents (New York) in 26 states. The International City/County Management Association (ICMA), National Association of Counties (NAC), and National Association of Local Government Environmental Professionals (NALGEP) have produced local government best practice guides based on more than 70 local innovative programs and strategies to air quality improvement in their areas (ICMA, 2016; NAC, 2016; NALGEP, 2016). A review by NALGEP (2016) classifies their initiatives into six categories: smart growth; pollution prevention; energy alternatives; transportation alternatives; outreach and communication; and, regional cooperation. Programs range from simple, low-cost, short-term efforts such as outreach campaigns to complex, costly, long-term investments and policies such as major retrofits of vehicle fleets or urban planning and development projects. Further review of these initiatives, along with best practice guides from the ICMA (2016) and NAC (2016), suggests local initiatives are not a duplication of state-level regulatory action. Rather, local governments appear to be focusing on the "carrot" and "sermon," more than the "stick" (Bemelmans-Videc, Rist, and Vedung, 1998). Regulations, particularly of stationary sources, are a heavy focus of state operations (Belden, 2001; 
This is an author-produced, peer-reviewed version of this article. The final, definitive version of this document can be found online at The American Review of Public Administration, published by SAGE. Copyright restrictions may apply. doi: 10.1177/0275074016680026

Potoski and Woods, 2002). On the other hand, the local approach is to encourage changes in individual behavior through incentives or removal of barriers. Outreach and communication programs are a popular mechanism to provide information to the public, as well as private and non-profit organizations. As a whole, local governments are building on efforts of their "partners" at the state and federal levels by finding avenues for initiatives that best meet local needs. (See ICMA (2016), NAC (2016), and NALGEP (2016) for information on local initiatives).

Local policy diffusion is a result of two issues: competition and state action. Competition from surrounding areas pressures local governments into innovation. Though competition in a multi-level governmental system is complex, innovation occurs in response to efforts from neighboring cities or in imitation of larger cities, with larger cities acting more independently (Walker, 2006; Shipan and Volden, 2005, 2008). Additionally, these competitive pressures to address policy issues connect to membership in Metropolitan Planning Organizations (MPOs) and developing policy networks (Krause, 2011). The development of a service-based economy has created a growing emphasis on environmental quality, spurring a "race to the top" between state and local governments predicated on environmental benefits (Kincaid, 2006; Rabe, 2013). These benefits include: public health impacts; environmental amenities associated with urban growth and development, and recreational, tourism, and retiree economies; and, public attitudes toward the environment that connect to candidate selection, legislative voting patterns, and direct democracy initiatives. (Clark, Lloyd, Wong, and Jain, 2002; Sharma, 2004; Wu, 2006; Poudyal, Hodges, and Cordell, 2008; Daniels, et al., 2013; EPA, 2016c). Additionally, state action or inaction forces local governments to expand or contract their policy initiatives. Local governments have no need to be redundant in operations, so if states are effectively managing a policy problem, there is little pressure for local innovation. However, if states are not effectively managing a problem, there is pressure, which can manifest either as states pushing responsibility to lower level governments or venue shopping by political interests (Shipan and Volden, 2005, 2008). The state influence explanation is supported by Woods and Potoski (2010)'s findings that state policy decentralization, local air issues, and environmental interests are the best predictors of local air initiatives.

\section{Modeling Local Government Membership in Public Service Delivery Networks}

As local government efforts in this area are largely varied, a broad definition is necessary to capture the various forms in which state and local efforts are networked. For the model, there is no assumption of specific types of active collaboration or implementation of a precise policy between networked actors, rather only local governments are working to deliver the same public service (i.e., air quality) as state governments, and there is some form of association between air offices. The form of association can range from official regional cooperative agreements to casual social networks created by professional associations. Previous findings have confirmed the influence of both ends of the range on facilitating collaboration, in both formal and informal forms. The model does not explicitly rule out collaboration, partnerships, or specified policy goals of any type. The model simply seeks to explain why local governments are entering an already existing policy implementation scheme in a new capacity. It does not consider the specific nature of the relationship between network organizations. Figure 1 displays a model for local government membership in public service delivery networks for air quality. Internal organizational factors are programmatic needs and/or policy problems and perceptions of availability of resources from potential partners. Organizations will seek to enter new networks when there is a pressing programmatic need to do so due to a policy problem. Furthermore, organizations will seek new networks when there is the perception of availability of resources from potential partners to address its policy problem. 
This is an author-produced, peer-reviewed version of this article. The final, definitive version of this document can be found online at The American Review of Public Administration, published by SAGE. Copyright restrictions may apply. doi: 10.1177/0275074016680026

Figure 1. Model for Local Government Membership in Air Quality Networks

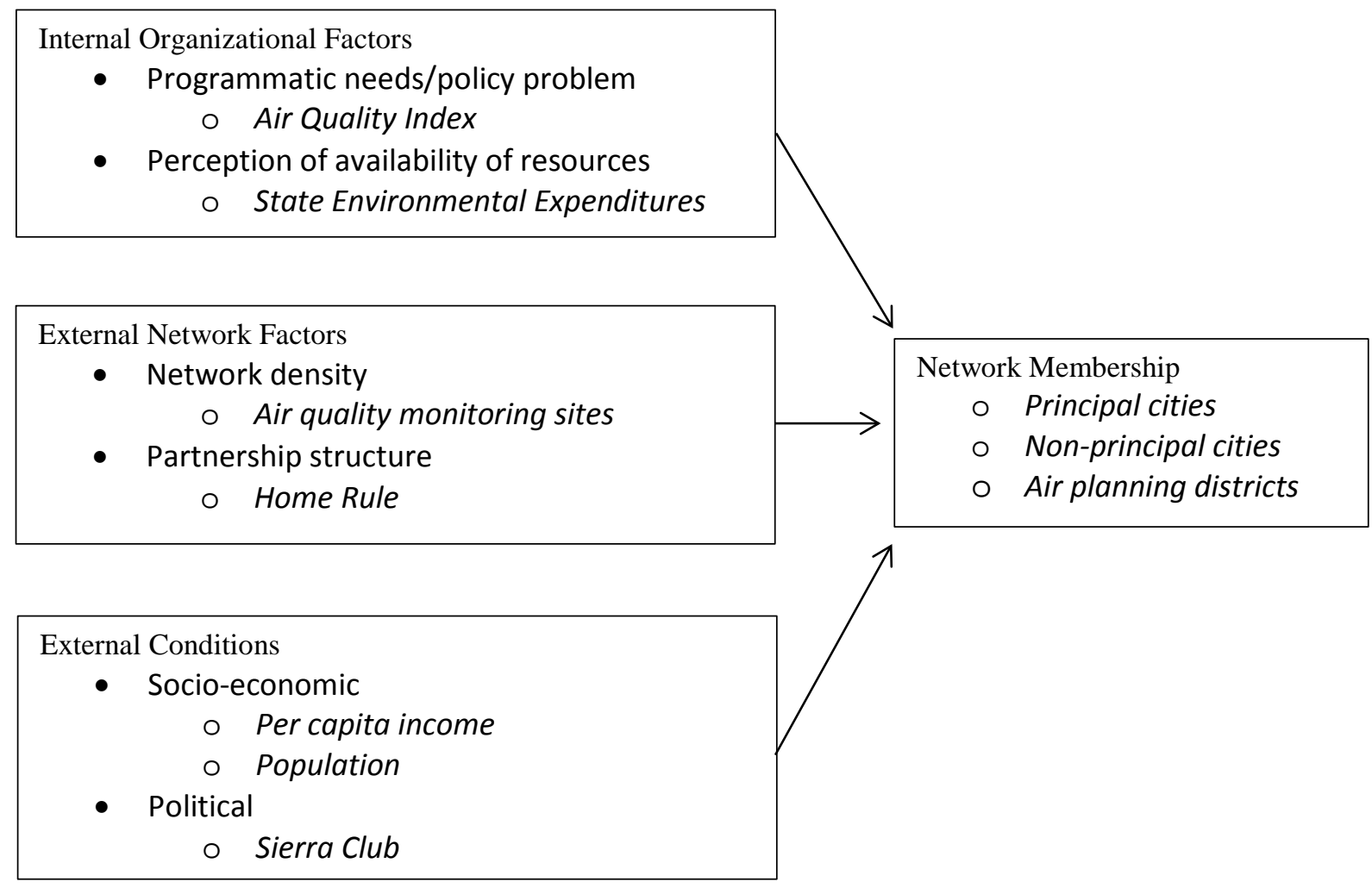

Applying this to local governments entering air quality networks, programmatic needs and policy problems are represented by existing air quality, and perceptions of resource availability by state-level spending on environmental programs. The most likely predictor of local initiatives is a public problem. Local governments facing a problem would be more likely to take initiative to provide better public services, compared to others not facing problems to the same extent. In other words, local air initiatives would be a product of poor air quality, as local governments would have a need to improve public services already provided by the state by expanding their role in networks. Therefore, as air quality decreases the likelihood of local initiatives should increase.

Furthermore, as states have primary legal authority for the CAA implementation, allocations for state-level operations amount to considerable resources for implementation. However, resource availability for operations differs between states. Perceptions of available resources would make states attractive potential partners for local governments with a policy problem. On the other hand, perceptions of limited resources would create the impression of limited benefits to partnership and serve as a deterrent to collaboration. Potential partners describe states here, because expanding initiatives in air quality does not specifically guarantee access to resources or active collaboration with state governments. Perception of the potential of partnership is a key factor in the motivation to seek further participation in a network. Additionally, as prior research connects spending by states to air quality at the local-level, there is a connection between state-level operations and local outcomes (Potoski and Woods, 2002; Fowler, 2013; Konisky and Woods, 2012). Therefore, as state expenditures increase the likelihood of local initiatives should increase as well.

External to organizations are network density and partnership structure. Organizations will seek to enter new networks when there are adequate existing network density and operations to make entry worthwhile, and the structure of the relationship between partners allows for independence. Applying this to entry into air quality networks, existing air quality monitoring sites represent network density and Home Rule represents partnership structure. States are the lynchpin in air quality management due to the structure of the CAA, so any network would have to focus around states and their relationships with local governments. However, not all states are facing the same challenges in distribution of operational resources. Air quality monitoring sites are a function of the geographic distribution of population centers, and ranges from 34 in California to one in Rhode Island (EPA, 2016a). The number of monitoring sites 
This is an author-produced, peer-reviewed version of this article. The final, definitive version of this document can be found online at The American Review of Public Administration, published by SAGE. Copyright restrictions may apply. doi: 10.1177/0275074016680026

captures the extent of state-level operations and potential for partners locally. ${ }^{1}$ While each monitoring site is part of state-level operations, it also represents local functions of those operations, which means individual administrators with network ties and functions. That is, with a single monitoring site, there is a concentrated network in Rhode Island with limited potential for entry and few collaborative opportunities to work with other individual network actors. On the other hand, with multiple monitoring sites, there are more locally situated state-level operations that offer opportunity to extract benefits. Networks with more extensive operations would attract local governments as partners. Therefore, as state monitoring sites increase the likelihood of local initiatives should increase as well.

Additionally, state-local relations are not the same everywhere; or, more to the point, structural power imbalances fluctuate. Based on application of Dillon's Rule or Home Rule, states can limit local government autonomy. Dillon's Rule creates limited authority for local government, based on a legal precedent, in which local governments may only partake in activities as authorized by the state government. On the other hand, Home Rule states have adopted provisions which expand local government authority through delegation of powers and limitation of state interference into local affairs (Krane, Rigos, and Hill, 2001; NLC, 2016). As such, local governments operating under Home Rule would have a more "open” relationship with states than those operating under Dillon's Rule. Local governments would be unlikely to enter networks that would provide them with limited independence. In other words, potential coercion by other partners may make local governments hesitant of expanding public service delivery, and thus, avoid these networks. Additionally, the very nature of state-local relations in the U.S. federal system allows for a certain degree of structural and relational "embeddedness," so the basic structural requirements for a successful network are likely already present (Krane, et al., 2001). The concern is whether that structure becomes too rigid and infringes on organizational independence. Therefore, local governments with broader authority should be more likely to take on air initiatives.

Socio-economic and political environments create external conditions which support the expansion of networks due to preferences for shared policy goals. Economic development is one of the most noted predictors of environmental quality, as it relates to both the production of pollutants through industrial processes and political attitudes towards environmental concerns (Bacot and Dawes, 1997; Sapat, 2004; Konisky and Woods, 2010, 2012). Additionally, population differences affect scale and scope of administration, so an MSA of 100,000 people would not face the same challenges as a $\mu$ SA of 25,000 people (Bacot and Dawes, 1997; Potoski and Woods, 2002; Konisky and Woods, 2010). As both population and per capita income increase so should the likelihood of local air initiatives. Finally, the political climate also provides external pressure for policy initiatives. Direct and indirect political pressures on policy processes connect environmental interest groups and environmental outcomes (Bacot and Dawes, 1997; Potoski and Woods, 2002; Sapat, 2004; Fowler, 2013). As environmental interest group strength increases so should the likelihood of local air initiatives.

Finally, as local governments differ in jurisdictional and operational capacities, network membership is likely to function differently depending on the type of local government. Not all cities and counties are equal in their roles and capacity within their areas. Principal cities have the mass of administrative capacity and political capital to effect change over the area, whereas secondary cities and counties are much more limited. For example, a principal city providing services to $70 \%$ of a metropolitan area would have more capacity to improve air quality through both changes in public behavior and its internal operations, compared to a secondary city only providing services to $10 \%$ of an area. On the other hand, due to operational sizes, taking on new initiatives would not require the same administrative capacity or political capital in secondary cities, compared to principal cities. Additionally, planning districts, typically established by SIPs, have limited authority, so their initiatives are not a function of the same factors city or county initiatives would be. Thus, there is an important difference between planning districts, and cities and counties. The separation of types of local governments allows for consideration of differing positions in networks, by identifying categories of local governments that may respond unequally to internal organizational and external network pressures.

Since capacity is more limited for non-principal cities, there should be more influence from both internal and external factors, as they are more likely to need the benefits of networks. Non-principal cities are limited in their capacity to address air quality and will need partnerships to do so effectively (Fowler, 2016). On the other hand, principal cities have greater capacity to unilaterally deal with policy issues, and have greater resources and independence; thus, the substantive influence of internal and external factors should be lower (Shipan and Volden, 2005, 2008; Fowler, 2016). 
This is an author-produced, peer-reviewed version of this article. The final, definitive version of this document can be found online at The American Review of Public Administration, published by SAGE. Copyright restrictions may apply. doi: 10.1177/0275074016680026

The same factors effecting conventional local governments are unlikely to have similar effects for air planning districts, as they are a function of SIPs and have little independent policy action. Thus, it is unlikely these factors will have the same impact on planning districts as principal and non-principal cities.

\section{Methodology}

\section{$\underline{\text { Dataset and Analysis }}$}

The dataset observes 497 MSAs and $\mu$ SAs in the U.S., which served as air quality monitoring sites in 2010. The MSAs and $\mu$ SAs represent all 50 states and range in size from 19,599,534 (New York City, NY) to 18,012 (Los Alamos, NM). Of the 497 MSAs and $\mu$ SAs in the dataset, 47 contain areas in two or more states. When measuring state-level variables for these MSAs or $\mu \mathrm{SAs}$, we used the multi-state averages. Two reasons led to observation at this level. First, MSAs and $\mu$ SAs serve as the basis for air quality monitoring and management. Second, it is impossible to separate the contexts of local governments operating in the same statistical areas, so data at the locallevel would lead to issues in observation. Logistic regression tests model 1 using a nominal dependent variable. Multinomial logistic regression tests model 2 using a multinomial dependent variable. Reported for all models are logistic coefficients. Statistical tests indicate there was no violation of assumptions of either logistic or multinomial logistic regression (Menard, 2002).

\section{Independent Variables}

Based on figure 1, there are three categories of independent variables: internal organizational, external network, and external conditions. These variables were operationalized based on extant literature on subnational environmental policy in the U.S. Table 1 displays variable descriptive statistics. First, internal organizational variables are air quality and state environmental expenditures. To measure air quality, the median annual Air Quality Index (AQI) is used. Since criteria pollutants are not comparable to each other and present different problems across areas, the EPA created the AQI to standardize measurement of air quality, and to create a more efficient means to evaluate program success. The AQI is a piecewise linear function of pollutant concentration measured on a scale from 0 to 100 , with 100 corresponding to ceilings for concentration under primary standards (EPA, 2016b). The EPA's AirData system provided data on MSA and $\mu$ SA AQI (EPA, 2016a). US Census Bureau provided data on state environmental expenditures, measured in thousands of dollars per capita (Census, 2016).

Second, external network variables include air quality monitoring sites and Home Rule. The EPA's AirData system also provided data on state monitoring sites, which were measured as a count variable. An ordinal variable was created to control for the effects of Home Rule versus Dillon's Rule. Currently, 31 states abide by Dillon's Rule, 10 states by Home Rule, and nine states with limited or modified application of Dillon's Rule1 (NLC, 2016). States abiding by Dillon's Rule were coded two; states with a limited or modified application of Dillon's Rule, one; and, states abiding by Home Rule, zero. National League of Cities (NLC) provided data on state-local relations (NLC, 2016).

Finally, external conditions include per capita income, population, and environmental interests. US Bureau of Economic Analysis (BEA) provided data on per capita income, measured as dollars per capita, and population, measured as 100,000s people per area (BEA, 2016). As previous scholars have done to control for environmental interest groups, Sierra Club membership is used here (Bacot and Dawes, 1997; Potoski and Woods, 2002; Sapat, 2004; Fowler, 2013). Sierra Club provided state-level membership data, which we converted into members per 10,000 state residents (Sierra Club, 2016). As boundaries do not limit political interests and they tend to be mobile within their state, this assumes state-level power influences at local politics.

\section{Dependent Variable}

Models rely on two operationalizations of dependent variables. First, as a nominal variable, the dependent variable is modeled as a dichotomy between MSAs and $\mu$ SAs with a local government operating an air quality office and MSAs and $\mu$ SAs without a local government operating an air quality office (base category). The NACAA provided data on air quality offices. This rests on four assumptions: 1 ) a dedicated air quality office internalized to a local government means that local government is operating air initiatives; 2) these air initiatives fall into a larger public service delivery scheme with actors at the federal- and state-level; 3) such an office would be a member of the national organization and engage in communication and association with other such offices; and, 4) local governments without such an 
This is an author-produced, peer-reviewed version of this article. The final, definitive version of this document can be found online at The American Review of Public Administration, published by SAGE. Copyright restrictions may apply. doi: 10.1177/0275074016680026

office are not undertaking major initiatives (Fowler, 2016). Those four assumptions satisfy the rather broad network definition being utilized by the model, where local governments are both working to a similar policy goal and creating an association with other clean air organizations through membership. At minimum, member offices have entered into a social network with other clean air offices. Of the 497 areas in the dataset, 19.9\% included air quality offices using these criteria.

Second, we further divided the nominal dependent variable into categories to reflect differences in types of local governments. As a multinomial variable, the dependent variable is modeled as four separate categories for MSAs and HSAs: 1) those without local governments operating air quality offices (base category); 2) those aligning with an air planning district at a regional-level; 3) those with a local government operating an air quality office, but not a principal city for the area; and, 4) those with a local government operating an air quality office and serving as a principal city for the area. The principal city is the incorporated city government with the largest population within the MSA or $\mu \mathrm{SA}$. In the event that a MSA or $\mu \mathrm{SA}$ has more than one local government operating air initiatives, we coded based on the local government with the highest level of operations. Using these criteria, of the 497 areas in the dataset, $6.2 \%$ included principal municipality air offices, $4.6 \%$ included non-principal municipality air offices, and $9.1 \%$ included air planning districts.

Table 1. Variable Descriptive Statistics ${ }^{2}$

\begin{tabular}{|l|l|c|c|c|c|}
\hline \multicolumn{1}{|c|}{ Variable } & \multicolumn{1}{|c|}{ Description } & $\begin{array}{c}\text { Mean (or } \\
\text { \%) }\end{array}$ & $\begin{array}{c}\text { Std. } \\
\text { Dev. }\end{array}$ & Min & Max \\
\hline $\begin{array}{l}\text { Nominal dependent } \\
\text { variable for air } \\
\text { offices }\end{array}$ & $\begin{array}{l}\text { Dummy variable comparing areas with } \\
\text { and without local air quality offices }\end{array}$ & $19.91 \%$ & .40 & 0 & 1 \\
\hline $\begin{array}{l}\text { Ordinal dependent } \\
\text { variable for air } \\
\text { offices }\end{array}$ & $\begin{array}{l}\text { Ordinal variable comparing areas with } \\
\text { principal municipality air offices, non- } \\
\text { principal municipality air offices, and air } \\
\text { planning districts to areas without local air } \\
\text { offices }\end{array}$ & $19.91 \%$ & .84 & 0 & 3 \\
\hline Air Quality Index & Annual median air quality index & 39.32 & 14.07 & 1.00 & 200.00 \\
\hline $\begin{array}{l}\text { State environmental } \\
\text { expenditures }\end{array}$ & $\begin{array}{l}\text { \$1,000s of state environmental } \\
\text { expenditures per capita }\end{array}$ & .094 & .110 & .022 & .751 \\
\hline Monitoring Sites & $\begin{array}{l}\text { Number of state-level air quality } \\
\text { monitoring sites }\end{array}$ & 15.82 & 7.48 & 1.00 & 34.00 \\
\hline Home Rule & $\begin{array}{l}\text { Ordinal dummy variable comparing } \\
\text { Dillon's Rule, modified Dillon's Rule, } \\
\text { and Home Rule states }\end{array}$ & .61 & .77 & 0 & 2 \\
\hline $\begin{array}{l}\text { Sierra Club } \\
\text { members }\end{array}$ & $\begin{array}{l}\text { State Sierra Club members per 10,000 } \\
\text { state residents }\end{array}$ & 18.72 & 10.44 & 4.37 & 44.57 \\
\hline Per capita income & \$1000s of personnel income per capita & 35494.84 & 7161.05 & 21672.00 & 98499.00 \\
\hline Population & 1000s of residents per statistical area & .523 & 1.391 & .180 & 195.995 \\
\hline
\end{tabular}

Findings and Discussion

Table 2 displays findings for model 1 using the nominal dependent variable. The AQI finding indicates MSAs and $\mu \mathrm{SAs}$ with poor air quality have an increased probability of local governments undertaking air initiatives. Additionally, as air quality monitoring sites increase, so does the probability of local air initiatives. Findings for Home Rule indicate local governments with more narrow authority are more likely to undertake air initiatives. However, as findings for model 2 suggests, air planning districts may be skewing this finding. Other findings are consistent with previous scholarship. As findings for population and Sierra Club suggest, MSAs and $\mu$ SAs with larger populations and stronger political interests have an increased probability of local initiatives. Findings for state-level expenditures and MSA and $\mu$ SA per capita income were not statistically significant in model 1. Finally, coefficients and statistical significance between models for all variables were consistent, suggesting reliability of results. The pseudo $\mathrm{R}^{2}$ indicates the model is a strong predictor of air initiatives at the local-level. 
This is an author-produced, peer-reviewed version of this article. The final, definitive version of this document can be found online at The American Review of Public Administration, published by SAGE. Copyright restrictions may apply. doi: 10.1177/0275074016680026

Table 2. Logistic Regression Results for Models 1

\begin{tabular}{|l|l|}
\hline All local air offices & Model 1 \\
\hline Air Quality Index & $.023^{* *}(.010)$ \\
State Expenditures & $6.04 \mathrm{E}-7(2.90 \mathrm{E}-6)$ \\
Monitoring Site & $.145^{* * *}(.024)$ \\
Home Rule & $.430^{*}(.191)$ \\
Sierra Club & $.067^{* * *}(.014)$ \\
Per Capita Income & $.0000377(.000021)$ \\
Population & $.000962^{* * *}(2.18 \mathrm{E}-7)$ \\
Constant & $-8.447^{* * *}(1.147)$ \\
\hline $\mathrm{N}$ & 497 \\
Pseudo $\mathrm{R}^{2}$ & .4112 \\
BIC & 353.8377 \\
AIC & 320.169 \\
LL & $-152.084^{* * *}$ \\
\hline 01. Standard errors in parenthesis. McFadden's Pseudo R ${ }^{2}$ is used.
\end{tabular}

Table 3 displays findings for model 2 using the multinomial dependent variable. The AQI finding indicates MSAs and $\mu \mathrm{SAs}$ with poor air quality have an increased probability of both principal and non-principal cities undertaking air initiatives, with a stronger substantive relationship for non-principal cities. This is consistent with findings from model 1. Additionally, the positive relationships for both state expenditures and site counts indicate principal and non-principal cities in states with higher spending and more monitoring sites are more likely to undertake air initiatives. The negative relationship for Home Rule in both models indicates principal and non-principal cities with broader authority are more likely to take initiative in air quality. This is in conflict with findings from model 1. However, the positive (albeit not statistically significant) relationship for air planning districts likely skewed results when local governments were not separated by type. Findings for per capita income and population indicate MSAs and $\mu$ SAs with larger populations and lower economic development have an increased probability of local air initiatives. No findings were statistically significant for air planning district in model 2. This is likely a result of air planning districts initiatives being of state creation rather than local action. Additionally, the findings for Sierra club membership were not statistically significant in model 3 for any category. Finally, for model 2, coefficients and statistical significance between models for all variables were consistent. For both models, coefficients and statistical significance for most variables display consistency, with a few exceptions. As a whole, this suggests reliability in findings. The pseudo $\mathrm{R}^{2}$ indicates all models are strong predictors of air initiatives at the local-level.

Table 3. Multinomial Logistic Regression Results for Model 2

\begin{tabular}{|l|l|l|l|}
\hline & Principal Cities & Non-Principal Cities & Planning Districts \\
\hline Air Quality Index & $.376^{*}(.148)$ & $3.172^{* *}(1.123)$ & $-.056(1.612)$ \\
State Expenditures & $.367^{* *}(.134)$ & $4.096^{* *}(1.440)$ & $.203(.767)$ \\
Monitoring Site & $3.110^{* * *}(.948)$ & $17.831^{* *}(6.249)$ & $2.318(2.360)$ \\
Home Rule & $-2.907^{*}(1.209)$ & $-9.625^{* *}(3.716)$ & $.050(9.044)$ \\
Sierra Club & $-.251(.186)$ & $.223(.4196)$ & $.822(2.697)$ \\
Per Capita Income & $-.002^{* * *}(.0005886)$ & $-.011^{* *}(.004)$ & $-.002(.005)$ \\
Population & $.273^{* * *}(7.77 \mathrm{E}-6)$ & $.439^{* *}(.0000158)$ & $.0000471(.0000369)$ \\
Constant & $-37.175^{* *}(13.523)$ & $-344.197^{* *}(122.113)$ & $-28.101(127.693)$ \\
\hline $\mathrm{N}$ & 497 & \\
Pseudo $\mathrm{R}^{2}$ & .3747 & & \\
BIC & 751.4756 & & \\
AIC & 738.6911 & & \\
LL & $-229.0547^{* * *}$ & & \\
\hline
\end{tabular}

Note: ${ }^{*}<.05, * *<.01, * * *<.001$. Standard errors in parenthesis. McFadden’s Pseudo $\mathrm{R}^{2}$ is used

Gleaned from model comparisons are five additional findings. First, AQI is an important and consistent indicator of local air initiatives. Findings for both models are consistent in the positive and statistically significant relationship (except for planning districts in model 2) between AQI and local initiatives. Thus, policy problems and/or 
This is an author-produced, peer-reviewed version of this article. The final, definitive version of this document can be found online at The American Review of Public Administration, published by SAGE. Copyright restrictions may apply. doi: 10.1177/0275074016680026

programmatic needs are a major and important driver of membership in networks. Second, while less consistent, findings for state-level expenditures do suggest perceptions of available resources from network partners are also an important element of network membership. Third, findings for both site count and home rule indicate network density and partnership structures effect network membership. For both models, there is a consistent positive, statistically significant relationship for the effects of site count on membership (except for planning districts in model 2). Additionally, model 2 indicates local governments with more autonomy are more likely to take initiative. This is inconsistent with model 1, which air planning districts may have skewed. Fourth, both internal organizational and external network factors influence types of local government differently. Clearly, model 2 suggests air planning districts do not function in the same way as other local governments. Furthermore, the substantive difference between findings for principal and non-principal cities illustrates the broader point. Both internal organizational (air quality index, state-level expenditures) and external network (site count, home rule) variables have a more substantive impact on non-principal cities than principal cities, while external conditions variables (Sierra Club, per capita income, and population) are comparable. This suggests principal and non-principal cities are playing a different role in these networks, as the same factors are having substantively more impact on one compared to the other. Finally, contextual factors, such as socio-economics and politics, affect network membership as well. In model 1, Sierra Club and population, and in model 2, per capita income and population are statistically significant predictors of membership. This suggests context plays a role in membership as well. These findings are, more or less, consistent across models and with expectations based on previous scholarship.

\section{Conclusions}

Networks represent an alternative to traditional structures in policy and governance processes. More specifically, for policy implementation, these are alternative inter-organizational relationships to hierarchical bureaucracies. Noteworthy for this research is that even within hierarchical relationships, networks can emerge when the specifics of programs allow for it. Local governments here are creating networks out of a previously existing hierarchical implementation scheme. The CAA, states, or the federal government do not govern initiatives from local governments to improve air quality. Local efforts are part of a larger collective effort to manage air quality, which moves beyond a traditional hierarchical relationship typically envisioned when analyzing federal-state-local relationships and replaces it with a network. Neither traditional federalism nor the textbook CAA implementation scheme effectively explains local government actions in this case. By taking initiative to expand programming beyond emissions enforcement, local governments have added to the toolbox of air quality management and created a network for service delivery. For those local governments, this is a function of need and opportunity. Local governments will seek networks, collaboration, or partnerships when there are not unilateral solutions to policy problems and there is a perception of available resources. Additionally, local governments will look for network ties when there is adequate opportunity for partnerships and a structure that allows for independence. When need and opportunity meet, local governments will join networks and expand public service delivery efforts to create better outcomes through joint action.

However, there are uneven effects across local governments for need and opportunity. As positioning and/or organizational capacity within the network changes, needs and opportunities will present different substantive pressures. This is likely a function of a difference in goals, operations, and/or constraints on individual local government types. Clearly, principal and non-principal cities and local planning districts function in very different ways, so the factors influencing their operations are different. Both internal organizational and external networks factors are more likely to affect local governments with limited capacity (non-principal cities). These governments are more likely to be in the need of networks due to their limited capacity, compared to principal cities. Thus, as needs grow, they are more likely to take advantage of opportunities for collaboration. Alternatively, the effects for planning districts are not the same, as they do not have the same independence in initiatives from the start since they are a created by SIPs. Planning districts function under a completely different set of internal and external pressures from municipalities. Thus, neither their roles in the network nor internal organizational and external network factors effecting network membership are the same. Future research should consider how differences in goals, operations, and/or constraints between these types of local governments influence the impact of internal and external pressures on local initiatives. Additionally, scholars should apply this framework to other intergovernmental networks for further insights to formation. 
This is an author-produced, peer-reviewed version of this article. The final, definitive version of this document can be found online at The American Review of Public Administration, published by SAGE. Copyright restrictions may apply. doi: 10.1177/0275074016680026

While the core of the CAA relies on a traditional inter-governmental relationship, emerging initiative trends by local governments have challenged that structure. For the CAA implementation, local governments are not serving as strictly as part of the textbook CAA implementation scheme. Rather, they have added a layer of complexity and created a public service delivery network in which partners are working to achieve a shared goal, but not implement the same policy. The CAA's implementation scheme is decades old, and is generally successful in achieving improved air quality in the US (GAO, 2007; Fowler, 2014). However, during that same period, both government and academic understanding of government have evolved drastically. In both practice and theory, there has been a transition from archaic implementation frameworks to public service delivery networks. Nevertheless, both state and federal CAA implementation schemes and strategies have not emulated this evolution. Local governments are currently proving that progress can occur when implementation schemes expand to include initiatives to address local environmental, social, economic, and political issues (NALGEP, 2016; NAC, 2016). Scholars should continue to analyze local government roles in air quality, and consider how alterations to the CAA's implementation framework can provide benefits in policy outcomes and governance.

As a whole, these findings provide some explanation of network membership by individual local governments in general, and local air initiatives and networks specifically. However, operationalization of variables and data limit these findings. In particular, the measurement of the dependent variable is vague and provides only limited indications of network association. Furthermore, the model does not consider the exact nature of network participation; rather it just focuses on the additional layer of public service delivery efforts. These findings are tentative and certainly not the final word on the topic, but do provide a further step in scholarship for understanding network formation. Further research should continue to consider why individual organizations, including private and non-private, join networks and seek collaboration and partnership. It is from the basis of understanding the need for networks that we can better understand their functions and outcomes.

\section{Notes}

1. Monitoring sites align with MSAs and $\mu S A s$ with one monitoring site per area.

2. For example, Alabama only applies Dillon's rule to certain types of municipalities, and Florida only applies Dillon's rule to taxing authority.

3. For the seven independent variables, correlations range from .321 to -.221. Variance Inflation Factor (VIF) statistics indicate no multicollinearity exists in any models presented.

\section{References}

Agranoff, R. and McGuire, M. (2001). Big Questions in Public Network Management Research. Journal of Public Administration Research \& Theory 11(3), pp. 295-326.

Andrew, S.A. (2009). Regional Integration through Contracting Networks: An Empirical Analysis of Institutional Collection Action Framework. Urban Affairs Review 44(3), pp. 378-402.

Andrews, R., Boyne, G., Meier, K., O’Toole, L. and Walker, R. (2011). Environmental and Organizational Determinants of External Networking. American Review of Public Administration 41(4), pp. 355-374.

Bacot, A.H. and Dawes, R.A. (1997). State Expenditures and Policy Outcomes in Environmental Program Management. Policy Studies Journal 25(3), pp. 355-370.

Belden, R.S. (2001). The Clean Air Act. Chicago: American Bar Association.

Bemelmans-Videc, M.L., Rist, R.C., and Vedung, E. (1998). Carrots, Sticks, and Sermons: Policy Instruments \& Their Evaluations. New Brunswick, NJ: Transaction Publishers.

Bunger, A.C. (2013). Administrative Coordination in Nonprofit Human Service Delivery Networks: The Role of Competition and Trust. Nonprofit and Voluntary Sector Quarterly 42(6), pp. 1155-1175.

Burstein, P. (2003). The Impact of Public Opinion on Public Policy: Review and an Agenda. Political Research Quarterly 56(1), pp. 29-40.

Clark, T.N., Lloyd, R., Wong, K.K., and Jain, P. (2002). Amenities Drive Urban Growth. Journal of Urban Affairs 24(5), pp. 493-515.

Daniels, D.P., Krosnick, J.A., Tichy, M.P., and Tompson, T. (2013). Public Opinion on Environmental Policy in the United States In M. Kraft and S. Kamieniecki (Eds.), Handbook of U.S. Environmental Policy (pp. 461486). New York: Oxford University Press. 
This is an author-produced, peer-reviewed version of this article. The final, definitive version of this document can be found online at The American Review of Public Administration, published by SAGE. Copyright restrictions may apply. doi: 10.1177/0275074016680026

Dodge, W. (2001). The Triumph of the Commons: Governing 21 ${ }^{\text {st }}$ Century Regions. Mountainview, CA: The Alliance for Regional Stewardship.

Environmental Council of the States. (2016). State Delegations-Clean Air Act. Retrieved (April 1), from http://www.ecos.org/section/states/enviro_actlist/states_enviro_actlist_caa

Feiock, R.C., Lee, I.W., Park, H.I., and Lee, K.H. (2010). Collaboration Networks among Local Elected Officials: Information, Commitment, and Risk Aversion. Urban Affairs Review 46(2), pp. 241-262.

Feiock, R.C. and Scholz, J.T. (Eds.). (2010). Self-Organizing Federalism: Collaborative Mechanisms to Mitigate Institutional Collective Action Dilemmas. Cambridge, UK: Cambridge University Press.

Fischer, M., Ingold, K., Sciarini, P., and Varone, F. (2012). Impacts of Market Liberalization on Regulatory Network: A Longitudinal Analysis of the Swiss Telecommunications Sector. Policy Studies Journal 40(3), pp. 435-457.

Frederickson, H.G. (1999). The Repositioning of American Public Administration. PS: Political Science \& Politics 32(4), pp. 701-712.

Fowler, L. (2013). Measuring Organization: Performance in Environmental Agencies. International Journal of Organization Theory \& Behavior 16(3), pp. 324-358.

Fowler, L. (2014). Assessing the Framework of Policy Outcomes: The Case of the U.S. Clean Air Act and Clean Water Act. Journal of Environmental Assessment Policy and Management 16(4).

Fowler, L. (2016). Initiative from the "Hidden” Partners of Air Quality. State \& Local Government Review 48(3), pp. 175-188.

Graddy, E.A. and Chen, B. (2006). Influences on the Size and Scope of Networks for Social Service Delivery. Journal of Public Administration Research and Theory 16(4), pp. 533-552.

Hjern, B. and Porter, D.O. (1981). Implementation Structures: A New Unit of Administrative Analysis. Organization Studies 2(3), pp. 211-227.

International City/County Management Association. (2016). "Air Quality: What is the Local Government Responsbility?” Retrieved (April 1), from http://icma.org/en/icma/knowledge_network/documents/kn/ Document/6377/Air_Quality_What_is_the_Local_Government_Responsibility

Isett, K.R. and Provan, K.G. (2005). The Evolution of Dyadic Interorganizational Relationships in a Network of Publicly Funded Nonprofit Agencies. Journal of Public Administration Research \& Theory 15(1), pp. 157173.

Jasny, L. (2012). Baseline Models for Two-Mode Social Network Data. Policy Studies Journal 40(3), pp. 458-491.

Kapucu, N., Hu, Q., and Khosa, S. (2014). The State of Network Research in Public Administration. Administration \& Society. Advance online publication.

Kemp, R.L. (2003). Regional Government Innovations: A Handbook for Citizens and Public Officials. Jefferson, NC: McFarland and Company.

Kincaid, J. (2006.) The Devolution Tortoise and the Centralization Hare R.A. Clucas (Ed.), Readings and Cases in State and Local Politics (pp. 57-68). Boston, MA: Houghton Mifflin.

Koliba, C.J., Mills, R.M., and Zia, A. (2011). Accountability in Governance Networks: An Assessment of Public, Private, and Nonprofit Emergency Management Practices Following Hurricane Katrina. Public Administration Review 71(2), pp. 210-220.

Konisky, D.M. and Woods, N.D. (2010). Exporting Air Pollution? Regulatory Enforcement and Environmental Free Riding in the United States. Political Research Quarterly 63(4), pp. 771-783.

Konisky, D.M. and Woods, N.D. (2012). Measuring State Environmental Policy. Review of Policy Research 29(4), pp. 544-569.

Krane, D., Rigos, N., and Hill, M. (2001). Home Rule in America: A Fifty-State Handbook. Washington, D.C.: CQ Press.

Krause, R.M. (2011). Policy Innovation, Intergovernmental Relations, and the Adoption of Climate Protection Initiatives by U.S. Cities. Journal of Urban Affairs 33(1), pp. 45-60.

Krueathep, W., Riccucci, N.M., and Suwanmala, C. (2010). Why Do Agencies Work Together? The Determinants of Network Formation at the Subnational Level of Government in Thailand. Journal of Public Administration Research \& Theory 20(1), pp. 157-185.

Laven, D.N., Krymkowski, D.H., Ventriss, C.L., Manning, R.E., and Mitchell, N.J. (2010). From Partnerships to Networks: New Approaches for Measuring U.S. National Heritage Area Effectiveness. Evaluation Review 34(4), pp. 271-298.

Lecy, J.D., Mergel, I.A., and Schmitz, H.P. (2014). Networks in Public Administration: Current Scholarship in Review. Public Management Review 16(5), pp. 643-665. 
This is an author-produced, peer-reviewed version of this article. The final, definitive version of this document can be found online at The American Review of Public Administration, published by SAGE. Copyright restrictions may apply. doi: 10.1177/0275074016680026

Lee, I.W., Feiock, R.C., and Lee, Y. (2012). Competitors and Cooperators: A Micro-Level Analysis of Regional Economic Development Collaboration Networks. Public Administration Review 72(2), pp. 253-262.

Lee, Y., Lee, I.W., and Feiock, R.C. (2012). Interorganizational Collaboration Networks in Economic Development Policy: An Exponential Random Graph Model Analysis. Policy Studies Journal 40(3), pp. 547-573.

LeRoux, K. and Carr, J.B. (2010). Prospects for Centralizing Services in an Urban County: Evidence from Eight Self-Organized Networks of Local Public Services. Journal of Urban Affairs 32(4), pp. 449-470.

Martineau, R.J. and Novello, D.P. (2004). The Clean Air Handbook, $2^{\text {nd }}$ edition. Chicago: American Bar Association, Section of Environment, Energy, and Resources.

Menard, S. (2002). Applied Logistic Regression Analysis, $2^{\text {nd }}$ edition. Thousand Oaks, CA: Sage Publications.

National Association of Clean Air Agencies. (2016). Find a State or Local Agency. Retrieved (April 1), from http://www.4cleanair.org/agencies

National Association of Counties. (2016). Air Quality Improvement: Guide for Local Governments. Retrieved (April 1), from http://www.naco.org/sites/default/files/documents/AQ_Factsheet\%20\%20Air\%20Quality\%20Improvement\%20Guide\%20for\%20Local\%20Governments.pdf

National Association of Local Government Environmental Professionals. (2016). Profiles of Local Clean Air Innovation: Empowering Communities to Meet the Air Quality Challenges of the $21^{\text {st }}$ Century. Retrieved (April 1), from http://www.nalgep.org/uploads/pdf/publi14.pdf

National League of Cities. (2016). Local Government Authority. Retrieved (April 1), from http://www.nlc.org/buildskills-and-networks/resources/cities-101/city-powers/local-government-authority.

Nicolaidis, K. and Howse, R. (Eds.). (2001). The Federal Vision: Legitimacy and Levels of Governance in the United States and the European Union. Oxford, UK: Oxford University Press.

O’Toole, L.J. (1997). Treating Networks Seriously: Practical and Research-Based Agendas in Public Administration. Public Administration Review 57(1), pp. 45-52.

O’Toole, L.J. (2000). Research on Policy Implementation: Assessment and Prospects. Journal of Public Administration Research \& Theory 10(2), pp. 263-228.

O’Toole, L.J. (2015). Networks and Networking: The Public Administrative Agendas. Public Administration Review 75(3), pp. 361-371.

Park, H. and Rethemeyer, R. (2014). The Politics of Connections: Assessing the Determinants of Social Structure in Policy Networks. Journal of Public Administration Research \& Theory 24(2), pp. 349-379.

Potoski, M. and Woods, N.D. (2002). Dimensions of State Environmental Policies: Air Pollution Regulation in the United States. Policy Studies Journal 30(2), pp. 208-227.

Poudyal, N.C., Hodges, D.G., and Cordell, H.K. (2008). The Role of Natural Resource Amenities in Attracting Retirees: Implications for Economic Growth Policy. Ecological Economics 68(1), pp. 240-248.

Provan, K.G. and Huang, K. (2012). Resource Tangibility and the Evolution of a Publicly Funded Health and Human Services Network. Public Administration Review 72(3), pp. 366-375.

Provan, K.G. and Lemaire, R.H. (2012). Core Concepts and Key Ideas for Understanding Public Sector Organizational Networks: Using Research to Inform Scholarship and Practice. Public Administration Review 72(5), pp. 638-648.

Provan, K.G. and Milward, H.B. (2001). Do Networks Really Work? A Framework for Evaluating Public Sector Organizational Networks. Public Administration Review 61(4), pp. 414-423.

Rabe, B.G. (2013). Racing to the Top, Bottom, or the Middle of the Pack? The Evolving State Government Role in Environmental Protection In N. Vig and M. Kraft (Eds.), Environmental Policy: New Directions for the 21 $1^{\text {st }}$ Century (pp. 30-53). Washington, DC: Sage.

Robins, G., Bates, L., and Pattison, P. (2011). Network Governance and Environmental Management: Conflict and Cooperation. Public Administration 89(4), pp. 1293-1313.

Sapat, A. (2004). Devolution and Innovation: The Adoption of State Environmental Policy Innovations by Administrative Agencies. Public Administration Review 64(2), pp. 141-151.

Scharpf, F.W. (1993). Coordination in Hierarchies and Networks In F.W. Scharpf (Ed.) Games in Hierarchies and Networks: Analytical and Empirical Approaches to the Study of Governance Institutions (pp. 7-23). Frankfurt, Germany: Campus Verlag.

Sharma, K.K. (2004). Tourism and Regional Development. New Delhi, India: Sarup and Sons.

Shipan, C. and Volden, C.M. (2005). Diffusion, Preemption, and Venue Shopping: The Spread of Local Antismoking Policies. Scholars in Health Policy Research Program Working Papers Series-31. Robert Wood Johnson Foundation.

Shipan, C. and Volden, C.M. (2008). The Mechanisms of Policy Diffusion. American Journal of Political Science 52(4), pp. 840-857. 
This is an author-produced, peer-reviewed version of this article. The final, definitive version of this document can be found online at The American Review of Public Administration, published by SAGE. Copyright restrictions may apply. doi: 10.1177/0275074016680026

Sierra Club. (2016). State Stats. San Francisco, CA: Sierra Club.

U.S. Bureau of Economic Analysis. (2016). Regional Data. Retrieved (April 1), from http://www.bea.gov/iTable/iTable.cfm?reqid=70\&step=1\&isuri=1\&acrdn=3\#reqid=70\&step=1\&isuri=1

U.S. Census Bureau. (2016). State Government Finances: Historical Data. Retrieved (April 1), from https://www.census.gov/govs/state/historical_data.html

U.S. Environmental Protection Agency. (2016a). Air Data. Retrieved (April 1), from http://www3.epa.gov/airdata/

U.S. Environmental Protection Agency. (2016b). Air Quality Index. Retrieved (April 1), from http://airnow.gov/index.cfm?action=aqibasics.aqi

U.S. Environmental Protection Agency. (2016c). Benefits and Costs of the Clean Air Act, 1990-2020. Retrieved (April 1), from http://www.epa.gov/clean-air-act-overview/benefits-and-costs-clean-air-act-1990-2020report-documents-and-graphics.

U.S. Environmental Protection Agency. (2016d). The Clean Air Act: A Partnership between Governments. Retrieved (April 1), from http://www.epa.gov/clean-air-act-overview/clean-air-act-partnership-amonggovernments

U.S. Environmental Protection Agency. (2016e). National Ambient Air Quality Standards. Retrieved (April 1), from http://www3.epa.gov/ttn/naaqs/criteria.html

U.S. Environmental Protection Agency. (2016f). SIP Status and Information. Retrieved (April 1), from http://www3.epa.gov/airquality/urbanair/sipstatus/

U.S. Government Accountability Office. (2007). Environmental Protection: EPA-State Enforcement Partnership Has Improved, but EPA's Oversight Needs Further Enhancement. Washington, DC: Government Printing Office.

Walker, R. M. (2006). Innovation Type and Diffusion: An Empirical Analysis of Local Government. Public Administration 84(2), pp. 311-335.

Winter, S.C. (2012). Implementation In B.G. Peters and J. Pierre (Eds.), The Sage Handbook of Public Administration (pp. 255-278). Thousand Oaks, CA: Sage.

Woods, N.D., and Potoski, M. (2010). Environmental Federalism Revisited: Second-Order Devolution in Air Quality Regulation. Review of Policy Research 27(6), pp. 721-739.

Wu, J.J. (2006). Environmental Amenities, Urban Sprawl, and Community Characteristics. Journal of Environmental Economics and Management 52(2), pp. 527-547. 